\title{
Serological diagnosis of infection of the urinary tract by yeasts
}

\author{
D. W. WARNOCK, D. C. E. SPELlER, J. A. MORRIS, AND P. H. MACKIE \\ From the Microbiology Department, Bristol Royal Infirmary, Bristol BS2 $8 \mathrm{HW}$
}

SYNOPSIS Precipitins to mannan and cytoplasmic antigens of Candida albicans and Torulopsi ${ }_{\mathscr{S}}^{\omega}$ glabrata were determined in 25 patients with colonization of the bladder urine by yeasts and in $2 \overline{8}$ control patients with bacteriuria. Precipitins were present in $64 \%$ of the patients with funguria and in $56 \%$ of the patients with bacteriuria. There was no correlation between the reactions obtainedo and the clinical significance of the yeast colonization. It is suggested that a single precipitin tese is unhelpful in the assessment of the significance of urinary colonization by yeasts in hospita? patients.

Yeasts are often isolated from urine specimens from hospital patients. As with bacteriuria, quantitative criteria can be applied (Ahearn et al, 1966), and in fresh specimens a count of $10^{5}$ or more colonyforming units per millilitre almost certainly implies that the yeast is not a contaminant but is genuinely colonizing the bladder urine. Most of the patients with significant funguria, however, appear to suffer no ill effects from this, often persistent, colonization (Schönebeck, 1972) and it is only the occasional patient in whom dramatic complications developblood stream or tissue invasion, urinary obstruction, etc. In others there may be some clinical indication, symptomatic or other, of harm from the colonization, but these more doubtful intimations of genuine infection may be difficult to assess, particularly against a background of other illness. It is the more important that harmful effects should be discerned now that we have in flucytosine an active and relatively non-toxic oral agent for the treatment of yeast infection of the urinary tract (Speller, 1975). Serological tests have been used in the assessment of such patients (Wise et al, 1972).

This investigation was undertaken to assess the usefulness of a single precipitin test in a series of patients with colonization of the bladder urine by yeasts.

\section{Material and methods}

PATIENTS AND CONTROLS

The 25 patients included in the funguria series were

Received for publication 10 February 1976 hospital in-patients from whom fresh catheter o mid-stream urines had yielded more than 100 colonies per $\mathrm{ml}$ of a yeast on at ieast two occasions?

The 25 control patients were from similar unitsç matched by age and sex with the patients in की०े funguria series but with significant bacteriuria (more than $10^{5}$ colonies per $\mathrm{ml}$ ).

Ten millilitres of blood was taken from eàctp patient and the serum was separated and stored ad $-20^{\circ} \mathrm{C}$ until required.

\section{CLINICAL ASSESSMENT}

The clinical and pathological findings in each patien? throughout his stay in hospital were analysed. The incidence in both series of patients of factors thoughis to predispose to urinary colonization and to fungas infection is given in table I. In each case the clinicad significance of the yeast infection was assessed an the patient was assigned to one of the following groups:

Y3 definite evidence of harmful effects of the yeast, eg, fungaemia, obstruction by yeast evidence of tissue invasion

Y2 some evidence of harmful effect, eg, urinar symptoms, fever, difficulty of diabetic controp, etc, for which no cause other than the yeasin could be discovered; favourable response tou eradication of the yeast

$Y 1$ benign colonization by yeasts; no evidence of any harmful effect of colonization

Y0 no urinary colonization by yeasts.

LABORATORY ASSESSMENT

Urine specimens were cultured for bacteria and of 


\begin{tabular}{lll}
\hline & Funguria series & Bacteriuria controls \\
\hline Total no. & 25 & 25 \\
Male & 11 & 11 \\
Female & 14 & 14 \\
Age-mean & $68 \cdot 8$ years & $68 \cdot 4$ years \\
-range & $36-91$ years & $35-87$ years \\
Urinary isolates & 16 Candida albicans & 10 coliform (lactose-fermenting) \\
& 8 Pseudomonas aeruginosa \\
Related urinary symptoms & 1 Candida parapsilosis & 2 Streptococcus faecalis \\
Pyuria & 5 & 12 \\
Previous catheterization & 16 & 17 \\
Previous antibacterial agents & 24 & 13 \\
Previous adrenocorticosteroids & 25 & 17 \\
Diabetes mellitus & 4 & 3 \\
Malignant disease & 10 & 1 \\
Fungal infection elsewhere & 5 & 8 \\
\hline
\end{tabular}

Table I Composition of series and controls: urinary and clinical data

Sabouraud's glucose peptone agar for yeasts by a semiquantitative standard loop method; the specimens were refrigerated and the counts were subsequently checked by the method of Miles and Misra (1938). Pyuria was defined as more than 10 leucocytes per high-power microscope field in a centrifuged deposit of the urine resuspended in one-tenth of its original volume.

Yeast isolates were identified first by the serum germ-tube test (Taschdjian et al, 1960). Germ-tubepositive isolates were assumed to be Candida albicans, and those giving a negative result were further identified by morphology in corn meal agar and by sugar assimilation and fermentation reactions (English, 1974).

\section{PREPARATION OF ANTIGENS}

Soluble cytoplasmic (somatic) antigens were obtained from $C$. albicans group $\mathrm{A}$ and Torulopsis glabrata yeast cells grown in glucose peptone broth for 24 hours at $37^{\circ} \mathrm{C}$. The cells were disrupted in a Braun MSK homogenizer. Solid debris was removed by high-speed centrifugation and the supernatant was lyophilized.

Mannan antigens were extracted and purified according to the method of Peat et al (1961) as modified by Kocourek and Ballou (1969).

The cytoplasmic antigens were reconstituted in saline containing $0 \cdot 1 \%$ sodium azide to concentrations of 30 and $3 \mathrm{mg}$ per $\mathrm{ml}$. The mannan antigens were reconstituted to 1.0 and $0.1 \mathrm{mg}$ per $\mathrm{ml}$.

\section{PRECIPITIN TEST}

Double diffusion tests were carried out in $1.5 \%$ Noble agar containing $0.1 \%$ sodium azide layered to a depth of $1.5 \mathrm{~mm}$ on glass plates. The central serum well was $12.5 \mathrm{~mm}$ in diameter and the peripheral wells were $4 \mathrm{~mm}$ in diameter and $6 \mathrm{~mm}$ from the central well. Diffusion was carried out in moist chambers for up to one week at room temperature. The plates were rinsed in $0.1 \mathrm{M}$ saline overnight, dried, and stained in $0.5 \%$ Coomassie Blue BL.

\section{NATURE OF PRECIPITIN REACTION}

Two types of precipitin reaction have been observed in double diffusion tests with $C$. albicans antigens (Faux, 1968):

1 A broad diffuse ' $H$ ' type reaction attributable to heat-stable polysaccharide antigen. The concentration of antigen used is critical, for if the concentration is too high the reaction will disappear.

2 A well-defined ' $R$ ' type reaction attributable to heat-labile protein antigen. For this reaction higher concentrations of the antigen are needed, and the reaction is less readily soluble in excess antigen.

The cytoplasmic antigens, containing both protein and some mannan, were used at higher concentrations than the mannan antigens in order to detect ' $R$ ' type precipitin reactions.

\section{Results}

CLINICAL AND MICROBIOLOGICAL FINDINGS The principal clinical features of the 50 patients in this investigation, together with the microbiological findings, are summarized in table $I$. The analysis of the two series of patients in terms of funguria and its clinical significance is given in table II. No patient had incontrovertible evidence of clinically significant yeast infection, and most of those with funguria had no evidence of harm from the colonization. The two patients in the control series who were assigned to the Y1 group developed funguria later in their hospital stay after the bacteriuria had been noted and the serum specimen obtained.

All seven patients in the funguria series, who were assigned to the $\mathrm{Y} 2$ group of probable significant infection, were diabetics; four had $T$. glabrata and 


\begin{tabular}{llllc}
\hline Series & \multicolumn{5}{l}{ Clinical significance } & group \\
\cline { 2 - 5 } & $Y 3$ & $Y 2$ & $Y 1$ & $Y O$ \\
\hline Funguria & 0 & 7 & 18 & 0 \\
Control bacteriuria & 0 & 0 & 2 & 23 \\
\hline
\end{tabular}

Table II Clinical assessment of significance

$Y 0=$ no funguria; $Y 1=$ benign funguria $; \mathbf{2}=$ probable significant infection; Y3 = definite significant infection (see Methods section).

three had $C$. albicans colonization. Four of these seven patients were treated with flucytosine $(100 \mathrm{mg}$ per kg daily for one week) with successful eradication of the yeast in three patients. Resistance to flucytosine with persistence of the yeast occurred in one patient.

\section{SEROLOGICAL FINDINGS}

The incidence of precipitating antibodies to $C$. albicans and T. glabrata is summarized in table III. Of the 25 patients with funguria, 16 gave ' $H$ ' type reactions to $C$. albicans mannan antigens; four of these patients also gave ' $H$ ' type reactions with the $C$. albicans cytoplasmic antigen. In addition, two patients gave ' $R$ ' type reactions with the $C$. albicans cytoplasmic antigen. Eleven of the 16 patients who reacted with the $C$. albicans antigens also gave ' $H$ ' type reactions with the $T$. glabrata antigens.

Of the 25 control patients, 12 gave ' $H$ ' type reactions with the $C$. albicans antigens; six of these patients also gave ' $H$ ' type reactions with the $T$. glabrata antigens. Two more control patients gave ' $H$ ' type reactions with the $T$. glabrata mannan antigen. There was no significant difference in the incidence of precipitins in the two series of patients $\left(\chi^{2}\right.$ test, $\left.\mathrm{P}>0.5\right)$.

The incidence of precipitins in the diabetic and non-diabetic funguria series patients is compared in table IV. Of the 10 diabetic patients in this series, six had precipitins to $T$. glabrata as compared with five of the 15 non-diabetic patients.

The incidence of precipitins in relation to the class of clinical significance in the 24 patients with either $C$. albicans or $T$. glabrata colonization is shown in table V. Of the 13 patients with C. albicans colonization included in the $\mathrm{Y} 1$ group, nine had precipitins to $C$. albicans and five also had preci-

\begin{tabular}{|c|c|c|c|c|c|c|}
\hline \multirow{3}{*}{ Patients } & \multicolumn{6}{|c|}{ Positive reactions to antigens of } \\
\hline & \multicolumn{3}{|c|}{ C. albicans } & \multicolumn{3}{|c|}{ T. glabrata } \\
\hline & $M$ & $M+C$ & $\begin{array}{l}\text { Per cent } \\
\text { positive }\end{array}$ & $\boldsymbol{M}$ & $M+C$ & $\begin{array}{l}\text { Per cent } \\
\text { positive }\end{array}$ \\
\hline $\begin{array}{l}\text { Diabetic (10) } \\
\text { Non-diabetic (15) }\end{array}$ & $\begin{array}{l}6 \\
6\end{array}$ & $\begin{array}{l}1 \\
3\end{array}$ & $\begin{array}{l}70 \cdot 0 \\
60 \cdot 0\end{array}$ & $\begin{array}{l}5 \\
5\end{array}$ & $\begin{array}{l}1 \\
0\end{array}$ & $\begin{array}{l}60 \cdot 0 \\
33 \cdot 3\end{array}$ \\
\hline
\end{tabular}

Table IV Incidence of precipitating antibodies in diabetic and non-diabetic patients

\begin{tabular}{|c|c|c|c|c|}
\hline & \multicolumn{2}{|c|}{$\begin{array}{l}16 \text { patients with } \mathrm{C} \text {. albicans } \\
\text { colonization }\end{array}$} & \multicolumn{2}{|c|}{$\begin{array}{l}8 \text { patients with } \mathrm{T} \text {. glabrata } \\
\text { colonization }\end{array}$} \\
\hline & $\begin{array}{l}\text { C. albicans } \\
\text { precipitins }\end{array}$ & $\begin{array}{l}\text { T. glabrata } \\
\text { precipitins }\end{array}$ & $\begin{array}{l}\text { C. albicans } \\
\text { precipitins }\end{array}$ & $\begin{array}{l}\text { T. glabrata } \\
\text { precipitins }\end{array}$ \\
\hline $\begin{array}{l}\text { Y1 } \\
\text { Y2 }\end{array}$ & $\begin{array}{l}9(69 \%) \\
1(33 \%)\end{array}$ & $\begin{array}{l}5(38 \%) \\
1(33 \%)\end{array}$ & $\begin{array}{l}2(50 \%) \\
4(100 \%)\end{array}$ & $\begin{array}{l}2(50 \%) \\
3(75 \%)\end{array}$ \\
\hline
\end{tabular}

Table $\mathrm{V}$ Incidence of precipitating antibodies in relations to clinical signs of infection

pitins to $T$. glabrata. Of the three diabetic patients $\stackrel{\frac{8}{\mathbb{C}}}{\mathbb{S}}$ with $C$. albicans colonization assigned to the $\mathrm{Y} 2 \mathrm{~B}$ group of probable significant infection, one had $\stackrel{\mathbb{Q}}{-}$ precipitins to both $C$. albicans and $T$. glabrata.

Of four Y1 patients with $T$. glabrata colonizatiog , ने two had precipitins to both $T$. glabrata and albicans. Three of four diabetic Y2 patients wit $T$. glabrata colonization had T. glabrata precipitins but all four of these patients also reacted with@ C. albicans antigens.

\section{Discussion}

The yeasts isolated in this investigation were those commonly encountered in such specimens (Ahearn et al, 1966; Speller and Davies, 1973). The funguria series and the control bacteriuria series differed in:several important clinical features. The funguria 3 . series had a greater incidence of diabetes mellitus, $\stackrel{\partial}{\circ}$ previous treatment with antibacterial agents, and previous urethral catheterization. The control serieso had a greater incidence of urinary symptoms. Six of the eight instances of $T$. glabrata colonization occurred in the 10 diabetic patients; this is a wellknown association (Marks et al, 1970).

\begin{tabular}{|c|c|c|c|c|c|c|c|}
\hline \multirow{3}{*}{ Series } & \multicolumn{6}{|c|}{ Numbers of patients giving positive reaction to antigens of } & \multirow{3}{*}{$\begin{array}{l}\text { Per cent } \\
\text { positive }\end{array}$} \\
\hline & \multicolumn{3}{|c|}{ C. albicans } & \multicolumn{3}{|c|}{ T. glabrata } & \\
\hline & Monly & Conly & $M+C$ & Monly & Conly & $M+C$ & \\
\hline $\begin{array}{l}\text { Funguria } \\
\text { Bacteriuria controls }\end{array}$ & $\begin{array}{r}12 \\
9\end{array}$ & $\begin{array}{l}\mathbf{0} \\
\mathbf{0}\end{array}$ & $\begin{array}{l}4 \\
3\end{array}$ & $\begin{array}{l}1 \\
5\end{array}$ & $\begin{array}{l}\mathbf{0} \\
\mathbf{0}\end{array}$ & $\begin{array}{r}10 \\
3\end{array}$ & $\begin{array}{l}64 \cdot 0 \\
56 \cdot 0\end{array}$ \\
\hline
\end{tabular}

Table III Incidence of precipitating antibodies to mannan $(M)$ and cytoplasmic $(C)$ antigens 
This investigation has shown that precipitating antibodies to mannan and cytoplasmic antigens can be detected in most hospital patients with fungal or bacterial colonization of the lower urinary tract. Indeed, there was no significant difference in the incidence of precipitins between the two groups. The presence of precipitins to $T$. glabrata mannan antigens in patients with $C$. albicans colonization is not surprising. Benham (1935) found that $T$. glabrata possessed antigens in common with $C$. albicans, and more recent studies have confirmed this observation (Hasenclever and Mitchell, 1960; Tsuchiya et al, 1961).

Precipitins were present, more commonly, against the mannan than the protein antigens in both series of patients, and reactions to protein antigens only were not found. Antibodies to the protein component of the $C$. albicans cytoplasmic antigen were, however, detected in two of the funguria series patients: this may be a significant finding. The detection of precipitins to protein antigens has been thought to indicate deep-seated candidal infection (Taschdjian et al, 1972), but at least one recent investigation has shown that antibodies giving rise to ' $R$ ' type reactions can occur in patients in the apparent absence of visceral infection (Stanley et al, 1972). Our findings lend further support to this observation.

The reason for the appearance of the antibodies to the protein component of the $C$. albicans cytoplasmic antigen is uncertain: Murray et al (1969) have suggested undetected candidaemia or transient deep-seated infection as possible reasons for the appearance of precipitins to cytoplasmic antigens. These two possibilities cannot be completely excluded in the two patients in our series giving ' $R$ ' type reactions, but in both cases the funguria appeared to be a transient, benign episode related to urethral catheterization and antibacterial therapy. Yeasts were not isolated from other sites in these patients, nor was there a previous history of fungal infection.

The incidence of precipitins in both our series of patients is higher than has been found in some other investigations (Stanley et al, 1972; Stanley and Hurley, 1974). The reasons for this are uncertain; it might be due to differing test methods and antigens used in the different investigations (Faux et al, 1975). It is probable that the failure to obtain reactions in previous investigations has been due to the use of too high concentrations of mannan antigens and that reactions have been obtained in patients with deepseated infection because larger amounts of antibodies were present. It is likely, however, that the higher incidence of precipitins in our patients is due to the type of patient included in this investigation. Our patients were in hospital, mostly elderly, all with other conditions, and most had been treated with antibacterial drugs. These factors could have contributed to an increasing colonization of the mouth or intestinal tract with yeasts and this in turn may have stimulated the production of antibodies.

In conclusion the high incidence of precipitin reactions in both series of patients, together with the lack of correlation between clinical and serological findings in the patients with funguria, leads us to suggest that the precipitin test has little to offer in the assessment of the significance in such patients of urinary tract colonization by yeasts.

We are indebted to Dr G. R. Jones (University of Glasgow) for providing the $T$. glabrata antigens, and to Mrs S. M. Robinson for assistance with yeast identification.

\section{References}

Ahearn, D. G., Jannach, J. R., and Roth, F. J., Jr. (1966) Speciation and densities of yeasts in human urine specimens. Sabouraudia, 5, 110-119.

Benham, R. W. (1935). Cryptococci-their identification by morphology and by serology. J. infect. Dis., 57, 255-274.

English, M. P. (1974). Identifying yeasts. Med. Lab. Technol., 31, 327-333.

Faux, J. A. (1968). Immunological studies of the antigens of Candida albicans in man. Ph.D. Thesis, University of London.

Faux, J. A., Stanley, V. C., Buckley, H. R., and Partridge, B. M. (1975). A comparison of different extracts of Candida albicans in agar gel double diffusion techniques. J. immunol. Methods, 6, 235-247.

Hasenclever, H. F. and Mitchell, W. O. (1960). Antigenic relationships of Torulopsis glabrata and seven species of the genus Candida. J. Bact., 79, 677-681.

Kocourek, J. and Ballou, C. E. (1969). Method for fingerprinting yeast cell wall mannan. J. Bact., 100, 1175-1181.

Marks, M. I., Langston, C., and Eickhoff, T. C. (1970). Torulopsis glabrata-an opportunistic pathogen in man. New Engl.J. Med., 283, 1131-1135.

Miles, A. A. and Misra, S. S. (1938). The estimation of the bactericidal power of the blood. J. Hyg. (Lond.), 38, 732-749.

Murray, I. G., Buckley, H. R., and Turner, G. C. (1969). Serological evidence of candida infection after open-heart surgery. J. med. Microbiol., 2, 463-469.

Peat, S., Whelan, W. J., and Edwards, T. E. (1961). Polysaccharides of bakers' yeast. Part IV. Mannan. J. chem. Soc., Part I, 29-34.

Schönebeck, J. (1972). Asymptomatic candiduria. Scand. J. Urol. Nephrol., 6, 136-146.

Speller, D. C. E. (1975). Yeasts in the urine (leading article). J. antimicrob. Chemother., 1, 253-254.

Speller, D. C. E. and Davies, M. G. (1973). Sensitivity of yeasts to 5-fluorocytosine. J. med. Microbiol., 6, 315-321.

Stanley, V. C. and Hurley, R. (1974). Candida precipitins in pregnant women: validity of the test systems used.J. clin. Path., 27, 66-69.

Stanley, V. C., Hurley, R., and Carroll, C. J. (1972). Distribution and significance of Candida precipitins in sera from pregnant women. J. med. Microbiol., 5, 313-320.

Tasclidjian, C. L., Burchall, J. J., and Kozinn, P. J (1960). 
Rapid identification of Candida albicans by filamentation on serum and serum substitutes. Amer. J. Dis. Child., 99, 212-215.

Taschdjian, C. L., Kozinn, P. J., Cuesta, M. B., and Toni, E. F. (1972). Serodiagnosis of candidal infections. Amer. J. clin. Path., 57, 195-205.
Tsuchiya, T., Fukazawa, Y., and Kawakita, S. (1961) ्ֶञ Serological classification of the genus Torulopsis. Sabour audia, 1, 145-153.

Wise, G. J., Ray, B., and Kozinn, P. J. (1972). The sero diagnosis of significant genitourinary candidiasis. J. Urol. 107, 1043-1046.

\section{The August 1976 Issue}

\section{THE AUGUST 1976 ISSUE CONTAINS THE FOLLOWING PAPERS}

Arterial wall lesions after pulmonary embolism, especially ruptures and aneurysms SIMON SEVITT

Development of germinal centres in the spleen in infants related to birth and unexpected death A. J. AL BARZANJI, S. R. PENNY, AND J. L. EMERY

Malignant lymphoma of the cervix uteri: histology and ultrastructure I. CARR, A. S. HILL, B. HANCOCK, AND F. E. NEAL

Carcinomas and carcinoid tumours of the appendix in a district general hospital R. A. JONES AND A. MaCFARLANE

Granuloma formation in patients receiving BCG immunotherapy J. A. WHITTAKER, D. P. BENTLEY, G. R. MELVILLE-JONES, AND A. J. SLATER

Effect of methotrexate therapy in psoriatics on the Ito cells in liver biopsies, assessed by point-counting D. HOPWOOD AND A. NYFORS

Section preparation of human marrow for light microscopy JOHN T. DANCEY, KURT A. DEUBELBEISS, AND LAURENCE A. HARKER with the technical assistance Of J. GREENAWAY

Computerization of a large antenatal serology service G. W. G. BIRD, M. WAIN, DIANA A. BATTEY, ANNE HOLMES, AND A. J. BUTLER

Anisocytosis and the C-1000 Channelyzer in macrocytic anaemia s. J. PROCTOR, J. R. COX, AND T. J. SHERIDAN

Regional quality control A. E. GREEN, R. D. HYDE, AND D. SMITH

Comparison of uridine uptake at 24 hours with thymidine uptake at 72 hours in phytohaemagglutininstimulated cultures of pregnant and other subjects T. E. BLECHER AND MILDRED J. THOMPSON
A comparative study of passive haemagglutination methods for the detection of hepatitis B surface antigen in routine hospital practice M. J. WITHERS, $\mathscr{S}_{-\infty}$ GILLIAN V. MCCAHILL, P. D. GRIFFITHS, R. B. HEATH,O J. R. PATTISON, AND D. S. DANE

Presumptive identification and antibiotic suscepti- $\mathbb{D}$ bility of group B streptococci A. M. M. JOKIPII AND $\mathbb{\mathbb { D }}$ LIISA JOKIPII

Infection with minute-colony-forming $\beta$-haemolytic $\overrightarrow{0}$ streptococci PAULINE M. POOLE AND G. WILSON

Serotypes of group B meningococci BARBARA M. TOBIN

D. M. JONES AM⿳亠口冋.

Assay of gentamicin in cerebrospinal fluid SUSAN DEACON

Absence of bacterial resistance to providone iodine ELIZABETH T. HOUANG, O. J. A. GILMORE, CLARE REID AND ELIZABETH T. SHAW

\section{Technical methods}

Detection of superficial gastric carcinoma in biopsies and resected stomachs J. D. DAVIES, A. J. C. TUDWAY, G. ROBERTS, AND G. MACHADO

Absorbance accuracy check on the LKB 8600 reaction rate analyser D. F. DAVIDSON

Application of scanning electron microscopy to the $\tilde{N}$ study of skin window preparations R. J. SOKOL, T. E. DURRANT, AND G. HUDSON

Letters to the Editor

Book reviews

Copies are still available and may be obtained from the PUBLISHING MANAGER, BRITISH MEDICAL ASSOCIATION, TAVISTOCK SQUARE, LONDON, WC1H 9JR, price $£ 2 \cdot 00$, including postage 